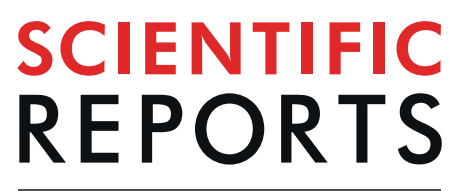

\title{
Management of soil pH promotes nitrous oxide reduction and thus mitigates soil emissions of this greenhouse gas
}

\author{
Catherine Hénault ${ }^{1,2^{*}}$, Hocine Bourennane ${ }^{2}$, Adeline Ayzac ${ }^{2}$, Céline Ratié ${ }^{3}$, Nicolas P. A. Saby ${ }^{3}$, \\ Jean-Pierre Cohan ${ }^{4}$, Thomas Eglin ${ }^{5}$ \& Cécile Le Gall ${ }^{6}$
}

While concerns about human-induced effects on the Earth's climate have mainly concentrated on carbon dioxide $\left(\mathrm{CO}_{2}\right)$ and methane $\left(\mathrm{CH}_{4}\right)$, reducing anthropogenic nitrous oxide $\left(\mathrm{N}_{2} \mathrm{O}\right)$ flux, mainly of agricultural origin, also represents an opportunity for substantial mitigation. To develop a solution that induces neither the transfer of nitrogen pollution nor decreases agricultural production, we specifically investigated the last step of the denitrification pathway, the $\mathrm{N}_{2} \mathrm{O}$ reduction path, in soils. We first observed that this path is mainly driven by soil $\mathrm{pH}$ and is progressively inhibited when $\mathrm{pH}$ is lower than 6.8. During field experiments, we observed that liming acidic soils to neutrality made $\mathrm{N}_{2} \mathrm{O}$ reduction more efficient and decreased soil $\mathrm{N}_{2} \mathrm{O}$ emissions. As we estimated acidic fertilized soils to represent $37 \%$ [27-50\%] of French soils, we calculated that liming could potentially decrease France's total $\mathrm{N}_{2} \mathrm{O}$ emissions by $15.7 \%$ [8.3-21.2\%]. Nevertheless, due to the different possible other impacts of liming, we currently recommend that the deployment of this solution to mitigate $\mathrm{N}_{2} \mathrm{O}$ emission should be based on local studies that take into account agronomic, environmental and economic aspects.

Agriculture is an important anthropogenic source of nitrous oxide $\left(\mathrm{N}_{2} \mathrm{O}\right)$, which has a global warming potential approximately 300 times higher than that of carbon dioxide $\left(\mathrm{CO}_{2}\right)$ on a molar basis and a 100 -year period ${ }^{1}$. In $2011, \mathrm{~N}_{2} \mathrm{O}$ accounted for $6 \%$ of radiative forcing change since $1750^{2}$. Arable soils emit more $\mathrm{N}_{2} \mathrm{O}$ to the atmosphere than any other anthropogenic source ${ }^{3}$, i.e., 4.2 teragrams (Tg) of the global anthropogenic flux of 8.1 Tg N $\mathrm{N}_{2} \mathrm{O}-\mathrm{N} \mathrm{yr}^{-1}$. Reducing soil $\mathrm{N}_{2} \mathrm{O}$ flux represents a substantial mitigation opportunity for agriculture to reduce its contribution to greenhouse gas emissions, and it also represents an opportunity to reduce radiative forcing at the global scale. The diversity of microbial metabolic pathways in soils provides a wealth of processes that form or consume $\mathrm{N}_{2} \mathrm{O}^{4}$. The microbial processes of denitrification in anoxic conditions and nitrification in the presence of oxygen $\left(\mathrm{O}_{2}\right)$ are generally admitted to be the main sources of $\mathrm{N}_{2} \mathrm{O}$ in managed and natural soils $^{4}$. The last step of the denitrification process (occurring classically or associated with co-denitrification or nitrification-denitrification $)^{4}$, i.e. the reduction of $\mathrm{N}_{2} \mathrm{O}$ to $\mathrm{N}_{2}$, is currently the only known pathway for the terrestrial removal of $\mathrm{N}_{2} \mathrm{O}$. Recently, in France, the potential of ten measures for mitigating agricultural greenhouse gas emissions was evaluated ${ }^{5}$ using a methodology with the calculation of both the specific potential abatement (i.e. the difference in emissions between a reference situation - baseline - and a situation where a specific measure is applied, related to the emissions of the reference situation) and the potential applicability (i.e. the surface area on which the application of the measure is technically possible ${ }^{5}$ ) for each measure. For example, one of these measures was to reduce the use of synthetic mineral fertilizers leading to an annual mitigation potential of approximately $0.013 \mathrm{Tg} \mathrm{N}-\mathrm{N}_{2} \mathrm{O}\left(6 \mathrm{Tg} \mathrm{CO}_{2} \mathrm{e}\right.$ - equivalent $\mathrm{CO}_{2}$ using the 100 -year global warming potential value published in 2006, i.e. 298) in 2030 at the scale of mainland France. Although ref. ${ }^{3}$ also considered that $\mathrm{N}_{2} \mathrm{O}$ abatement could preferentially be achieved by attenuating known sources of $\mathrm{N}_{2} \mathrm{O}$ emissions since $\mathrm{N}_{2} \mathrm{O}$ has no significant terrestrial sink, we hypothesized in this study that strategies to mitigate $\mathrm{N}_{2} \mathrm{O}$ emissions from agricultural

${ }^{1}$ Agroécologie, AgroSup Dijon, INRAE, Univ. Bourgogne Franche-Comté, F-21000, Dijon, France. ${ }^{2}$ URSOLS, INRAE, 45075, Orléans, France. ${ }^{3}$ Infosol, US1106, INRAE, 45075, Orléans, France. ${ }^{4}$ ARVALIS- Institut du Végétal Route de Châteaufort - RD 36 -ZA des Graviers, 91190, Villiers le Bacle, France. ${ }^{5}$ ADEME, Direction Bioéconomie et Energies Renouvelables, Service Forêts, Alimentation et Bioéconomie, F-49000, Angers, France. ${ }^{6}$ TERRES INOVIA, Avenue Lucien Brétignières, 78850, Thiverval Grignon, France. *email: catherine.henault@inra.fr 
soils could be based on the promotion of the last step of the denitrification pathway, i.e. the reduction of $\mathrm{N}_{2} \mathrm{O}$ into $\mathrm{N}_{2}$. There are different advantages of managing soil $\mathrm{N}_{2} \mathrm{O}$ reduction for mitigating $\mathrm{N}_{2} \mathrm{O}$ emissions: (i) the $\mathrm{N}_{2}$ final form of this transformation is inert, and no transfer of nitrogen pollution occurs during $\mathrm{N}_{2} \mathrm{O}$ reduction; (ii) certain studies on this specific step of the nitrogen cycle, catalysed by the $\mathrm{N}_{2} \mathrm{O}$ reductase enzyme encoded by the nos $Z$ gene, have provided conclusive results regarding the quantitative detection of the abundance of the nos $Z$ gene and regarding the proportion of denitrifiers in relation to total bacteria in soils ${ }^{6}$, and also, an inhibitor of this transformation (acetylene) can be used in the laboratory for experimental purposes ${ }^{7}$; (iii) previous reports have shown variations in the functioning of this transformation from soil to soil and suggest a link between a soil's capacity to reduce $\mathrm{N}_{2} \mathrm{O}$ and the intensity of in situ $\mathrm{N}_{2} \mathrm{O}$ emissions ${ }^{8}$; and (iv) there is no interference between a soil's capacity to reduce $\mathrm{N}_{2} \mathrm{O}$ and agricultural production. Moreover, the capacity of soil to reduce $\mathrm{N}_{2} \mathrm{O}$ can be characterized through a laboratory test (ISO/TS 20131-2) derived from the laboratory protocol used in ref. ${ }^{8}$ that provides quantitative indicators $\left(r_{\max }\right.$ and index) with rules of interpretation (the higher the $r_{\max }$ and index are, the lower the capacity of soil to reduce $\mathrm{N}_{2} \mathrm{O}$ ). We therefore developed this study to test the following hypotheses: (i) the capacity of soil to reduce $\mathrm{N}_{2} \mathrm{O}$ affects the intensity of in situ soil $\mathrm{N}_{2} \mathrm{O}$ emissions ${ }^{8}$; (ii) the capacity of soil to reduce $\mathrm{N}_{2} \mathrm{O}$ is determined by biogeochemical properties, i.e., the a priori soil $\mathrm{pH}$ and soil organic carbon content"; and (iii) the management of these properties can modify the capacity of a given soil to reduce $\mathrm{N}_{2} \mathrm{O}$ into $\mathrm{N}_{2}$ and therefore the intensity of soil $\mathrm{N}_{2} \mathrm{O}$ emissions at the field scale. During this study, we successively (i) examined in the laboratory the extent to which the capacity of soil to reduce $\mathrm{N}_{2} \mathrm{O}$ is determined by soil biogeochemical properties, (ii) tested under field conditions how the management of soil $\mathrm{pH}$ and soil organic matter affects the capacity of soil to reduce $\mathrm{N}_{2} \mathrm{O}$ and the intensity of soil $\mathrm{N}_{2} \mathrm{O}$ emissions, and (iii) calculated at the national scale the $\mathrm{N}_{2} \mathrm{O}$ emission mitigation that could be achieved by managing relevant soil biogeochemical properties.

\section{Results}

Biogeochemical determinism of the capacity of soil to reduce $\mathbf{N}_{2} \mathbf{O}$. We sampled 90 selected sites within the framework of the French Soil Monitoring Network (RMQS - Réseau de Mesure de la Qualité des Sols) ${ }^{10}$. Amongst the soil properties routinely analysed during the RMQS program (Supplementary Information 1_1), those used for the selection of sites were $\mathrm{pH}$, soil organic carbon content, land use and geographical position. The distributions of these variables among the selected sites were consistent with the total RMQS (Supplementary Information 1_2). We determined the capacity of these soils to reduce $\mathrm{N}_{2} \mathrm{O}$ through soil laboratory incubations according to ISO/TS 20131-2 derived from ref. ${ }^{8}$ to determine the indicators $r_{\max }$ and index (respectively, the maximum ratio of the accumulated $\mathrm{N}_{2} \mathrm{O}$ during incubation and a combination of $\mathrm{r}_{\max }$ and the time of accumulation of $\mathrm{N}_{2} \mathrm{O}$ during incubation). During all the soil incubations, we observed the production and consumption of $\mathrm{N}_{2} \mathrm{O}$, at soil specific rates. We did not observe any variation of $\mathrm{N}_{2} \mathrm{O}$ concentration over time for the treatment with $\mathrm{N}_{2} \mathrm{O}$ and $\mathrm{C}_{2} \mathrm{H}_{2}$, validating that in the experimental conditions imposed, $\mathrm{C}_{2} \mathrm{H}_{2}$ totally inhibits $\mathrm{N}_{2} \mathrm{O}$ reduction. Some examples of the calculation of the $\mathrm{r}_{\max }$ and index indicators are presented in Supplementary Information 2. All $r_{\max }$ and index values obtained are shown on the RMQS grid (Fig. 1).

Taking into account the meaning of these indicators, the rule of interpretation proposed in ISO/TS20131-2 and the concept of soil phenotypes ${ }^{11}$, we a priori classified the soils into three phenotype classes: [soil $]_{\mathrm{PHN}_{2} \mathrm{ORED}+\text {, }}$ able to reduce $\mathrm{N}_{2} \mathrm{O}$ ( $\mathrm{r}_{\max }$ and index lower than 0.4 and 30 , respectively); [soil $]_{\mathrm{PHN}_{2} \mathrm{ORED}-}$, unable or nearly unable to reduce $\mathrm{N}_{2} \mathrm{O}$ ( $\mathrm{r}_{\max }$ higher than 0.8 or index higher than 50 ); and others, called [soil] $]_{\mathrm{PHN}_{2} \mathrm{ORED}+/-}$, that have an intermediate capacity to reduce $\mathrm{N}_{2} \mathrm{O}$. Among the 90 subset sites, we found that 36 sites $(40 \%)$ were poorly able to reduce $\mathrm{N}_{2} \mathrm{O}$ ([soil $]_{\mathrm{PHN}_{2} \mathrm{ORED}^{-}}$), while 29 sites $(32 \%)$ were very efficient at reducing $\mathrm{N}_{2} \mathrm{O}\left([\text { soil }]_{\mathrm{PHN}_{2} \mathrm{ORED}+}\right)$ and 25 sites $(28 \%)$ were intermediate ([soil $\left.]_{\mathrm{PHN}_{2} \mathrm{ORED}+/-}\right)$. The detailed results are presented in Supplementary Information 3.

Soil $\mathrm{pH}$ appeared to be the factor that explained most of the variability of a soil's capacity to reduce $\mathrm{N}_{2} \mathrm{O}$, explaining $61 \%$ and $59 \%$ of $r_{\max }$ and index variability, respectively, for all the statistical methods used (linear regression, partial least square regression ${ }^{12}$, generalized boosted models ${ }^{13}$ and classification and regression trees coupled to factorial discriminant analysis ${ }^{14,15}$ ). Contrary to one of our hypotheses, the soil organic carbon content did not appear to be a predictor of the capacity of a soil to reduce $\mathrm{N}_{2} \mathrm{O}$. We observed that a soil's capacity to reduce $\mathrm{N}_{2} \mathrm{O}$ can be predicted using a partial least square (PLS) model based on soil $\mathrm{pH}$, the cation exchange capacity (CEC) determined by the cobalt-hexamine method described in NF X31-130 ( $\left.\mathrm{cmol} \mathrm{kg}^{-1}\right)$ and ref. ${ }^{16-18}$ and, the soil clay content $\left(\mathrm{g} \mathrm{kg}^{-1}\right)$. The following empirical pedotransfer equations were obtained (Eqs. 1 and 2, with the $r$ value being the linear correlation coefficient between the measured and predicted values of each indicator):

$$
\begin{gathered}
r_{\text {max }}=-0.4 p H+0.026 \text { CEC }-0.001 \text { Clay }+3.13 \quad \mathrm{r}=0.88 \\
\text { Index }=-94.18 p H+7.47 \text { CEC }-0.25 \text { Clay }+645.12 \quad \mathrm{r}=0.90
\end{gathered}
$$

Root mean square error is 0.17 and 2.05 for Eqs. 1 and 2, respectively. Moreover, a generalized boosted model (GBM) linked $\mathrm{pH}$ and $\mathrm{r}_{\max }$ through a step function (Fig. 2).

The predictive quality of this function was estimated using a leave-one-out cross-validation step with 300 repetitions. We estimated the determination coefficient to be 0.64 and RMSE 0.22 . This function suggests that (i) soils with $\mathrm{pH}<6.4$ have a very low capacity to reduce $\mathrm{N}_{2} \mathrm{O}\left(\mathrm{r}_{\max }>0.8\right)$, and (ii) soils with $\mathrm{pH}>6.8$ are able to reduce $\mathrm{N}_{2} \mathrm{O}$ efficiently $\left(\mathrm{r}_{\max }<0.4\right)$, and that the path of $\mathrm{N}_{2} \mathrm{O}$ reduction becomes efficient across a $\mathrm{pH}$ range of only 6.4 to 6.8 .

Classification and regression trees (CART) combined with factorial discriminant analysis (FDA) revealed 8 index-pH classes with a clearly consistent transition where $\mathrm{pH}$ was between $\sim 6.4$ and $\sim 7$ (Supplementary Information 4_1) for soils exhibiting a high index compared to soils exhibiting a low index.

Taken together, the results from this statistical processing converge to reveal (i) that $\mathrm{pH}$ can be used as a predictor of a soil's capacity to reduce $\mathrm{N}_{2} \mathrm{O}$ and (ii) that $\mathrm{N}_{2} \mathrm{O}$ reduction is poor when $\mathrm{pH}$ is lower than 6.4 and totally 


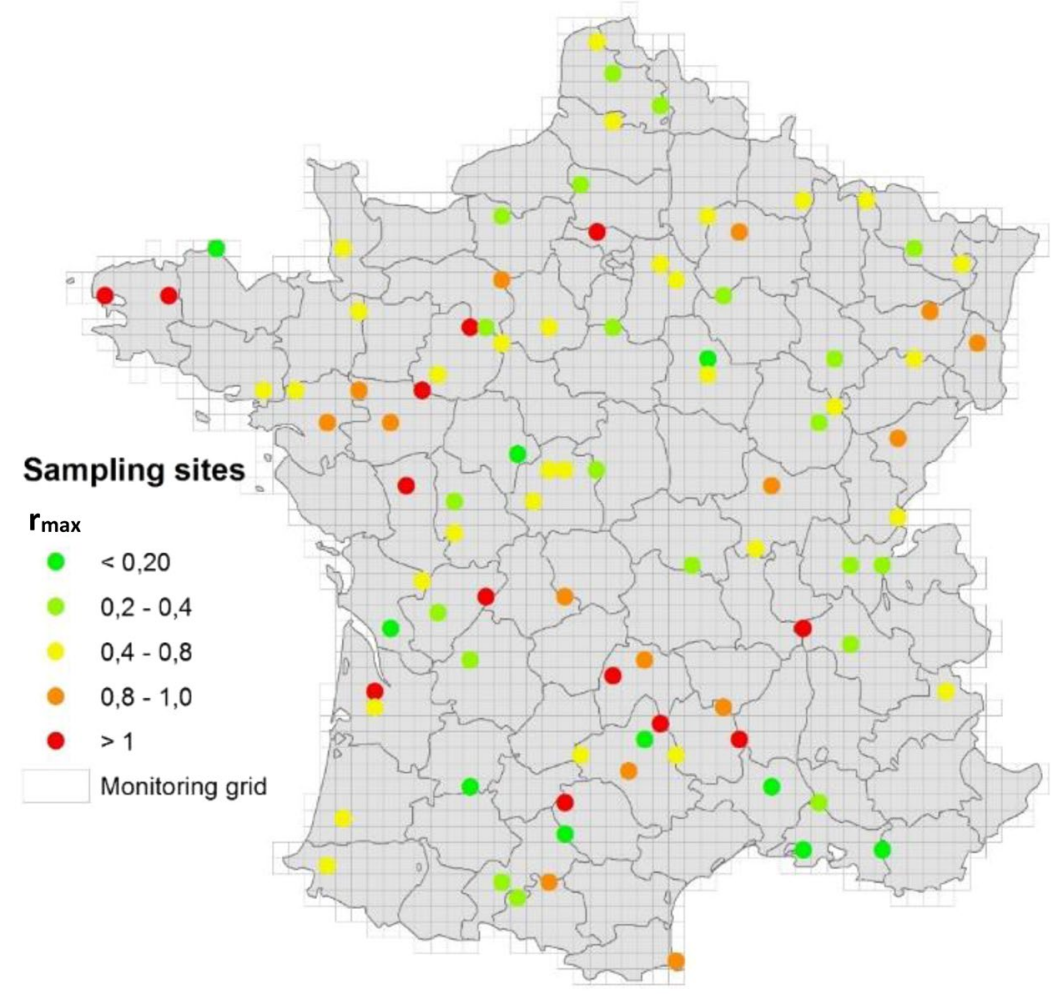

Figure 1. The capacity of soils to reduce $\mathrm{N}_{2} \mathrm{O}$, expressed as the $\mathrm{r}_{\max }$ indicator and shown on the RMQS grid.

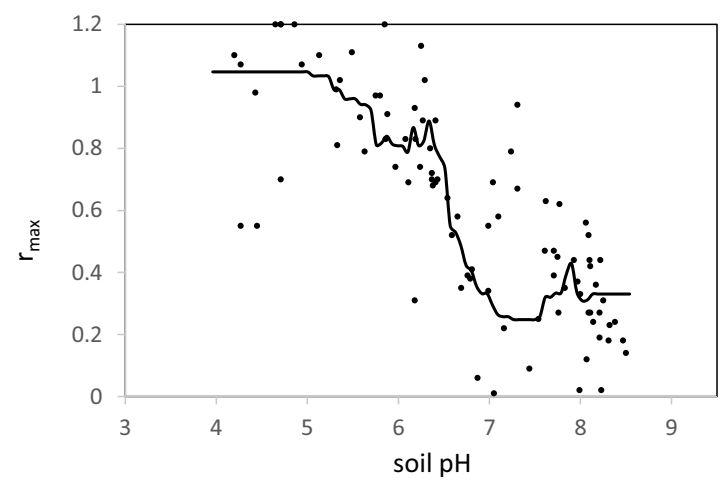

Figure 2. The experimental points of $\mathrm{r}_{\max }$ against soil $\mathrm{pH}$ and the function relating $\mathrm{r}_{\max }$ and soil $\mathrm{pH}$ obtained by the GBM.

efficient at a $\mathrm{pH}$ higher than 6.8-7 with a transient zone of efficiency in the 6.4-6.8 pH range, these limits being consistent with the a priori proposed classes of phenotypes.

Effect of liming on soil in situ $\mathrm{N}_{2} \mathrm{O}$ emissions. In situ experiments (E1 and $\mathrm{E} 2$ ) were performed to test how the management of soil $\mathrm{pH}$ and of soil carbon content affects the capacity of soil to reduce $\mathrm{N}_{2} \mathrm{O}$ and thus the level of soil $\mathrm{N}_{2} \mathrm{O}$ emissions. E1 was a two-year experiment testing the liming effect, and E2 was a one-year experiment testing the individual effects of liming and carbon addition on $\mathrm{N}_{2} \mathrm{O}$ emissions and the capacity of soil to reduce $\mathrm{N}_{2} \mathrm{O}$. During these experiments, we classically observed peaks of $\mathrm{N}_{2} \mathrm{O}$ emissions after $\mathrm{N}$ fertilizer applications (Fig. 3). These peaks reached different levels, due to site and annual climate conditions. The dynamics of $\mathrm{N}_{2} \mathrm{O}$ emissions were observed to be significantly different in limed plots compared to control ones in E1 (2013-2014 and 2014-2015) and in E2. $\mathrm{N}_{2} \mathrm{O}$ emission peaks were clearly lower in limed plots compared to the controls. During E2, the addition of organic C did not affect the overall dynamics of $\mathrm{N}_{2} \mathrm{O}$ emissions.

Soil temperature, moisture, and mineral nitrogen contents were not affected by liming at either site. We observed a peak of ammonium content just after the addition of organic matter in E2 while the other parameters (soil temperature, moisture and nitrate contents) were not affected by the treatments throughout the experiment (Supplementary Information 5). Soil bulk density was 1.45 at both sites which nevertheless differed with 

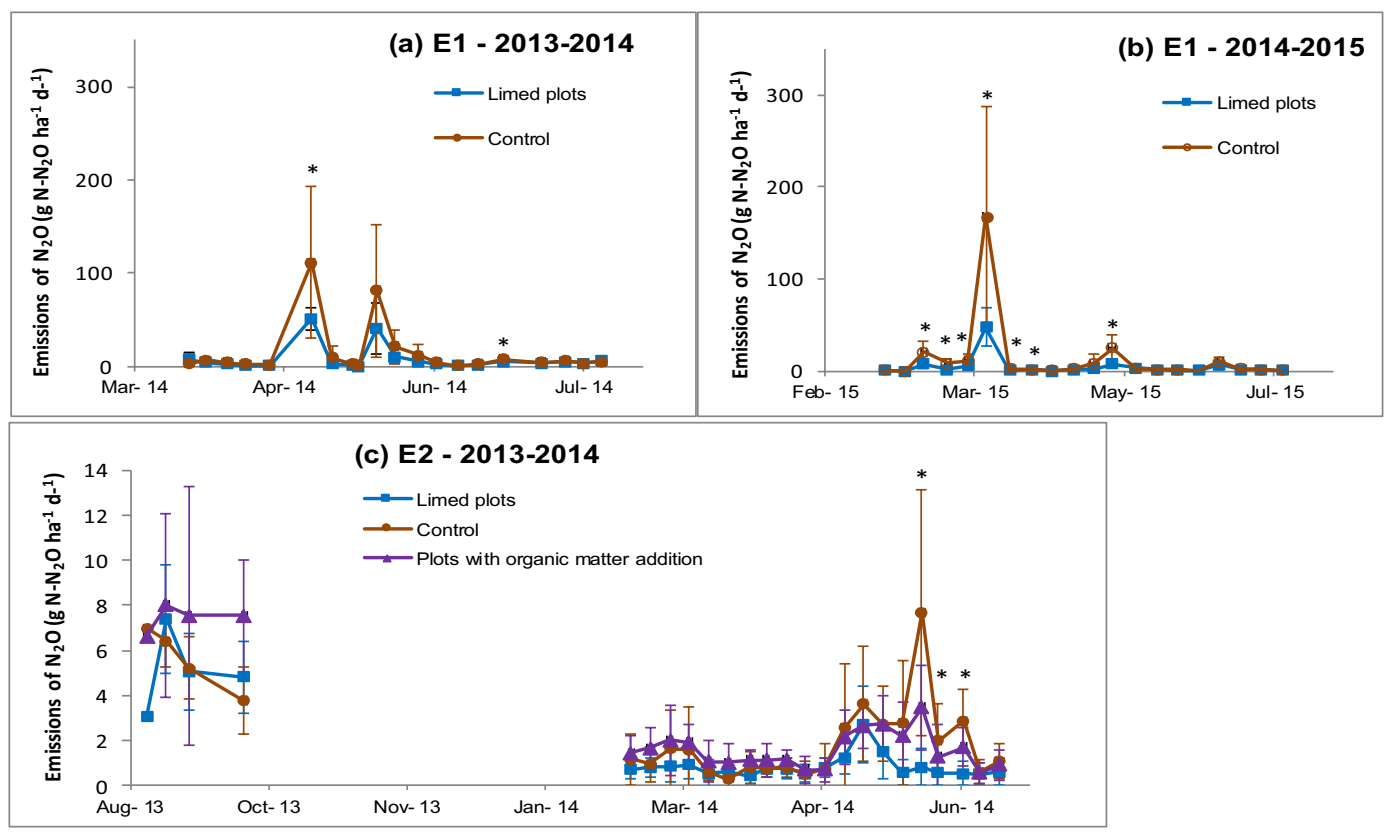

Figure 3. In situ $\mathrm{N}_{2} \mathrm{O}$ emissions measured (mean and standard deviations obtained from the 9 replicates per treatment) in E1 (upper panel) and E2 (lower panel). *Indicates significant $(\mathrm{p}<0.05)$ differences for results obtained on limed plots and control ones. In E1, liming events were of $1 \mathrm{t} \mathrm{CaO}$ applied in September 2013 and 2014. Nitrogen fertiliser was spread on $14 / 05 / 2014\left(60 \mathrm{~kg}\right.$ of $\left.\mathrm{N} \mathrm{ha}^{-1}\right)$ and on $\left.09 / 03 / 2015(70 \mathrm{~kg} \mathrm{of} \mathrm{N} \mathrm{ha})^{-1}\right)$, on $30 / 03 / 2015\left(50 \mathrm{~kg}\right.$ of $\left.\mathrm{N} \mathrm{ha}^{-1}\right)$, and on ${ }^{1} 0 / 05 / 2015\left(60 \mathrm{~kg}\right.$ of $\left.\mathrm{N} \mathrm{ha}^{-1}\right)$. In E2, liming event was of $1.5 \mathrm{t} \mathrm{CaO}$ in September 2013 and organic matter was applied at the same date. Mineral fertilisers were spread on 2/05/2014 $\left(50 \mathrm{Kg} \mathrm{N} \mathrm{ha}^{-1}\right)$ and on 9/05/2014 (50 Kg N ha $\left.{ }^{-1}\right)$. The "pig manure" plots did not receive the second input.

respect to soil moisture. This was always low in E2 $(<18 \%)$ while it reached values as high as $25 \%$ in E1. This corresponded to a WFPS (water filled pore space) ${ }^{19}$ lower than $60 \%$ in E2 and with values as high as $80 \%$ in E1, suggesting that the denitrification process would have occurred rarely and inefficiently in E2, though temporarily and intensively in $\mathrm{E} 1$. While differences in $\mathrm{pH}$ were observed between the control and limed plots in both experiments, we also observed a difference in the capacity of soil to reduce $\mathrm{N}_{2} \mathrm{O}$ (Fig. 4). Both indicators ( $\mathrm{r}_{\max }$ and index) decreased as $\mathrm{pH}$ increased, indicating that the capacity of soil to reduce $\mathrm{N}_{2} \mathrm{O}$ becomes more efficient at a higher $\mathrm{pH}$, consistent with the results obtained during the laboratory experiments. On the other hand, the addition of organic $\mathrm{C}$ in $\mathrm{E} 2$ did not affect the capacity of the soil to reduce $\mathrm{N}_{2} \mathrm{O}$.

Using Eq. 3, we determined the potential abatement effect of liming on $\mathrm{N}_{2} \mathrm{O}$ emissions. The values obtained were 49\% in 2013-2014 and 66\% in 2014-2015 in E1 and 26\% in 2013-2014 in E2, leading to a rough estimation (median of previous values) of the potential abatement of $\mathrm{N}_{2} \mathrm{O}$ emissions due to liming of $49 \%$.

$$
\text { abatement }=\frac{\text { mean }\left(\mathrm{N}_{2} \mathrm{O}\right)_{\text {control }}-\text { mean }\left(\mathrm{N}_{2} \mathrm{O}\right)_{\text {limed }}}{\text { mean }\left(\mathrm{N}_{2} \mathrm{O}\right)_{\text {control }}}
$$

With

mean $\left(\mathrm{N}_{2} \mathrm{O}\right)_{\text {control }}$ : Annual mean of $\mathrm{N}_{2} \mathrm{O}$ emissions measured in the control plots $\left(\mathrm{g} \mathrm{N}^{-\mathrm{N}_{2}} \mathrm{O}\right.$ ha $\left.{ }^{-1} \mathrm{y}^{-1}\right)$

mean $\left(\mathrm{N}_{2} \mathrm{O}\right)_{\text {limed }}$ : Annual mean of $\mathrm{N}_{2} \mathrm{O}$ emissions measured in the limed plots $\left(\mathrm{g} \mathrm{N}-\mathrm{N}_{2} \mathrm{O}\right.$ ha $\left.{ }^{-1} \mathrm{y}^{-1}\right)$

The results obtained in the field were consistent with the results obtained in the laboratory. On both scales, we observed that increasing $\mathrm{pH}$ promoted $\mathrm{N}_{2} \mathrm{O}$ reduction with $\mathrm{pH}$ increase, consistent with a decrease of in situ $\mathrm{N}_{2} \mathrm{O}$ emission. Also on both scales, we did not detect any significant effect of soil organic carbon on $\mathrm{N}_{2} \mathrm{O}$ reduction or on in situ $\mathrm{N}_{2} \mathrm{O}$ emission. Moreover, the effect of increasing soil pH on both the capacity of soil to reduce $\mathrm{N}_{2} \mathrm{O}$ and on soil in situ $\mathrm{N}_{2} \mathrm{O}$ emissions occurred almost immediately.

Consistent simulations (differences between the dynamics of measures and simulations were not significant, RMSE was lower than 2) obtained with the NOE algorithm (Supplementary Information 5) suggest that denitrification was the main process involved in $\mathrm{N}_{2} \mathrm{O}$ emission in $\mathrm{E} 1$ while nitrification was the main process involved in $\mathrm{N}_{2} \mathrm{O}$ emission in E2. This difference was mainly due to the differences in soil water filled pore space (WFPS) between these two situations, since it was high in the poorly drained situation in E1 and low in the well-drained situation in E2. Introducing the specific measured $\mathrm{r}$-values for describing the $\mathrm{N}_{2} \mathrm{O}$ reduction, made it possible to obtained reasonably well predicted abatement values.

Assessment of the mitigation potential at the national scale. We then assessed the potential applicability of these results at the national scale, across all of France, assuming that liming can be applied to all fertilized cultivated or grassland soils. Using the total RMQS database composed of 2145 sites, we assessed that fertilized cultivated and grassland soils represent $41 \%$ and $19 \%$, respectively, of the soils in France, together 

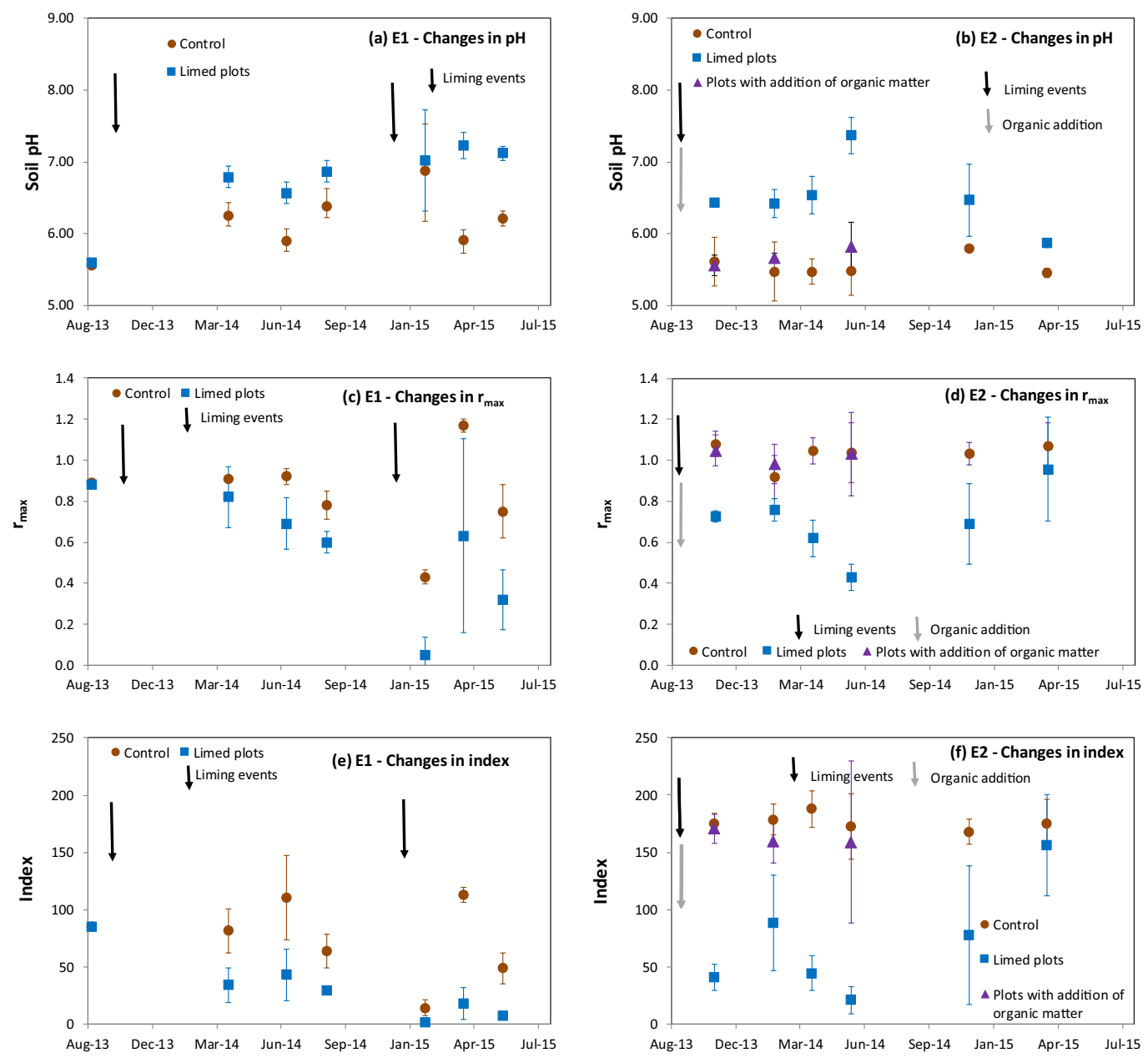

Figure 4. Changes in the indicators ( $\mathrm{pH}, \mathrm{r}_{\max }$ and index) of the capacity of soil to reduce $\mathrm{N}_{2} \mathrm{O}$ during E1 (left) and E2 (right). Error bars represent standard deviations $(n=3)$.

accounting for $60 \%$ of soils in France and corresponding to weighted contribution of $68 \%$ and $32 \%$ for cropped and grassland soils, respectively. Different approaches ("CART-FDA", "cumulative frequency", "map_rmqs") were used, each involving a combination of the three indicators $\left(\mathrm{pH}, \mathrm{r}_{\max }\right.$ and/or index) of the capacity of soil to reduce $\mathrm{N}_{2} \mathrm{O}$. All three approaches were developed into three steps: (i) the quantification of some of these indicators at the national scale, (ii) the thresholding per phenotype, and (iii) the weighting per land use. Intermediate calculations of these three approaches are presented in Supplementary Information 4.

The application of the eight index-pH classes defined by CART-FDA (Supplementary Information 4_1) to the total RMQS database indicated that $35 \%$ of the cropped soils and $65 \%$ of the grassland soils had an index higher than 30 , leading to an estimation of a potential applicability of $45 \%$ of the fertilized soil surface.

The "cumulative frequency" approach (Supplementary Information 4_2) indicated a potential applicability of $61 \%$ of the fertilized soil surface, with $46 \%$ of soils being [soils $]_{\mathrm{PHN}_{2} \mathrm{ORED}-}$ and $15 \%$ being $[\text { soils }]_{\mathrm{PHN}_{2} \mathrm{ORED} \pm}$.

The "map_rmqs approach" (Supplementary Information 4_3) indicated that the area of soils with a low capacity to reduce $\mathrm{N}_{2} \mathrm{O}$ ([soil $\left.]_{\mathrm{PHN}_{2} \mathrm{ORED}-}\right)$ was $38 \%$, while that of soils that very efficiently reduced $\mathrm{N}_{2} \mathrm{O}\left([\text { soil }]_{\mathrm{PHN}_{2} \mathrm{ORED}_{+}}\right)$ was $15 \%$, and soils that were intermediate ([soil $]_{\mathrm{PHN}_{2} \mathrm{ORED} \pm}$ ) accounted for $47 \%$.

After estimating the potential applicability based on different approaches (Table 1), we applied the values of potential abatement. We used values observed during previous field experiments. We distinguished full potential abatement $(49 \%)$ for $[\text { soils }]_{\mathrm{PHN}_{2} \mathrm{ORED}_{-}}$and half of full potential abatement $(25 \%)$ for $[\text { soils }]_{\mathrm{PHN}_{2} \mathrm{ORED}_{+} /-}$. We introduced a confidence interval for this estimation, corresponding to the low and high potential abatement values we observed previously, i.e., 26 and $66 \%$.

The potential for mitigating $\mathrm{N}_{2} \mathrm{O}$ emissions by liming acidic fertilized soils was then assessed as $15.7 \%(8.3-21.2 \%)$ at the national scale in France. As soil $\mathrm{N}_{2} \mathrm{O}$ emissions were estimated to represent $6.5 \%$ of the total national emissions of anthropogenic greenhouse gas on $\mathrm{CO}_{2} \mathrm{e}$ basis, we assessed a mitigation of $1.02 \%(0.5-1.4 \%)$ of this total national emission of anthropogenic greenhouse gas. This is in the same order of magnitude as the assessment of mitigation based on the decreased use of nitrogen fertilizer proposed by ref. ${ }^{5}$. 


\begin{tabular}{|c|c|c|c|c|c|c|c|c|c|}
\hline \multirow[b]{3}{*}{ Approaches } & \multirow{3}{*}{$\begin{array}{l}\text { Potential } \\
\text { abatment }\end{array}$} & \multirow{3}{*}{\begin{tabular}{|l}
$\begin{array}{l}\text { Representativity of } \\
\text { fertilised soils }\end{array}$ \\
$\%$ \\
\end{tabular}} & \multicolumn{3}{|c|}{ Potential applicability } & \multirow{2}{*}{\multicolumn{2}{|c|}{$\begin{array}{l}\text { Potential of } \\
\text { mitigation } \\
\text { of soil } \mathrm{N}_{2} \mathrm{O} \\
\text { emission at the } \\
\text { France Scale }\end{array}$}} & \multirow{3}{*}{\begin{tabular}{|l}
$\begin{array}{l}\text { Contribution } \\
\text { of soil } \mathrm{N}_{2} \mathrm{O} \\
\text { emissions to } \\
\text { total national } \\
\text { emissions of } \\
\text { anthropogenic } \\
\text { GHG }\end{array}$ \\
$\%$
\end{tabular}} & \multirow{3}{*}{\begin{tabular}{|l|} 
Potential for \\
mitigating \\
$\mathrm{N}_{2} \mathrm{O}$ emission \\
inside the \\
total national \\
emissions of \\
anthropogenic \\
GHG \\
$\%$ \\
\end{tabular}} \\
\hline & & & \multirow{2}{*}{\begin{tabular}{|l|} 
Total \\
$\%$
\end{tabular}} & \multirow{2}{*}{\begin{tabular}{|l|} 
Soil $\mathrm{PhN}_{2}$ Ored $^{-}$ \\
$\%$
\end{tabular}} & \multirow{2}{*}{$\begin{array}{l}\text { Soil } \\
\text { PhN }_{2} \mathrm{Ored}^{+/-} \\
\%\end{array}$} & & & & \\
\hline & & & & & & $\%$ & $\%$ & & \\
\hline \multirow{3}{*}{ "CART-FDA" } & Median & 60 & & 45 & & 49 & & 6.5 & 0.86 \\
\hline & Lowest & 60 & & 45 & & 26 & & 6.5 & 0.46 \\
\hline & Highest & 60 & & 45 & & 66 & & 6.5 & 1.16 \\
\hline \multirow{3}{*}{ "Cumulative Frequencies" } & Median & 60 & 61 & 46 & 15 & 49 & 25 & 6.5 & 1.02 \\
\hline & Lowest & 60 & 61 & 46 & 15 & 26 & 13 & 6.5 & 0.54 \\
\hline & Highest & 60 & 61 & 46 & 15 & 66 & 33 & 6.5 & 1.38 \\
\hline \multirow{3}{*}{ "Map from RMQS" } & Median & 60 & 84 & 38 & 47 & 49 & 25 & 6.5 & 1.13 \\
\hline & Lowest & 60 & 84 & 38 & 47 & 26 & 13 & 6.5 & 0.62 \\
\hline & Highest & 60 & 84 & 38 & 47 & 66 & 33 & 6.5 & 1.52 \\
\hline \multicolumn{7}{|c|}{ Global estimation (median of values obtained per each approach } & 15.73 & 6.50 & 1.02 \\
\hline
\end{tabular}

Table 1. Estimated benefit of liming as a method for $\mathrm{N}_{2} \mathrm{O}$ emission mitigation obtained by the different approaches "CART-FDA, "cumulative frequencies" and "map_RMQS", using the indicators $\mathrm{pH}, \mathrm{r}_{\max }$ and index.

\section{Discussion}

Using the framework of a potential "Technical Readiness Level Scale" dedicated to the reduction of GHG emissions, this study allowed for (i) advancing the concept of managing the microbial $\mathrm{N}_{2} \mathrm{O}$ reduction path, based on investigations conducted in the laboratory, (ii) completing the critical stage of field demonstrations and therefore (iii) calculating the potential mitigation at the national scale, consistent with international agreements on climate change.

The laboratory study of the $\mathrm{N}_{2} \mathrm{O}$ reduction path (in view of its field management) proved very positive since it validated the hypothesis that the factor explaining most of the variability of this path is soil $\mathrm{pH}$, as this soil property can be managed for example by liming acidic soils with different materials ${ }^{20}$ and by preventing soil acidification ${ }^{21}$.

The role of soil $\mathrm{pH}$ in soil $\mathrm{N}_{2} \mathrm{O}$ emissions was previously reported in the literature $\mathrm{e}^{9,22}$ and was mainly explained by the particularly high sensitivity of $\mathrm{N}_{2} \mathrm{O}$ reduction to low soil $\mathrm{pH}$ that prevents the reduction of $\mathrm{N}_{2} \mathrm{O}$ primarily by precluding the successful assembly of functional $\mathrm{N}_{2} \mathrm{O}$ reductase ${ }^{23}$. Due to its large sample size and the relevant distribution of soil samples properties, this current study further provides information indicating quantitative precision of the relationship between soil $\mathrm{pH}$ and the $\mathrm{N}_{2} \mathrm{O}$ reduction. First, even if the hypothesis of a linear relationship could not be rejected, a more complex pattern - as described by Fig. 2 - appeared, which concurs with the nonlinear relationship previously observed by ref. ${ }^{24}$. Second, $\mathrm{N}_{2} \mathrm{O}$ reduction appeared inefficient at $\mathrm{pH}<6.4$ but was very efficient at $\mathrm{pH}>6.8$, with an intermediate zone of activation. These values are consistent with the laboratory experiment reported in ref. ${ }^{23}$ and performed at $\mathrm{pH}$ values of 4.0, 6.1 and 8.0, during which the authors also observed that low soil $\mathrm{pH}$ prevented the reduction of $\mathrm{N}_{2} \mathrm{O}$. Moreover, the targeted value of $\mathrm{pH}$ was observed to exceed 6.8. Recently, ref. ${ }^{22}$ also highlighted the $\mathrm{pH}$ value of 6.8 , based on the observation that the default $\mathrm{EF}$ (emission factor) value of $1.0 \%$ for agricultural soil proposed by the IPCC is relevant at this particular $\mathrm{pH}$ value and increases as $\mathrm{pH}$ decreases. From both the agronomic and environmental standpoints, a soil $\mathrm{pH}$ value of 6.8 appears to be reached with a reasonable input and by maintaining ecosystem equilibrium ${ }^{21}$. Recently, ref. ${ }^{25}$ gained insight into the impact of liming on soil and crop processes together with functional aspects. As liming influences all elements in soils, ref. ${ }^{25}$ highlighted the clear positive impacts of liming for crops by increasing $\mathrm{P}$ availability, decreasing the uptake of toxic heavy metals, and preserving and improving the physical properties of soils. Nevertheless, ref. ${ }^{25}$ also noted that although there is a positive yield response for more crops, liming could also lead to the development of different crop diseases and deficiencies in trace-elements. Consequently, they proposed that liming management should be adjusted according to crop type within a given rotation. While ref. ${ }^{20}$ reported that the target soil $\mathrm{pH}$ for cropped land in the $\mathrm{UK}$ is set at 6.5, this study suggests that raising it slightly to 6.8 , while obviously taking into account sensitivity to crop disease, could greatly increase the environmental benefits of liming through $\mathrm{N}_{2} \mathrm{O}$ emission mitigation. Soil CEC also appeared to improve the prediction of the indicators of the capacity of soils to reduce $\mathrm{N}_{2} \mathrm{O}$. The influence of CEC together with that of $\mathrm{pH}$ is consistent with the assumption that soil exchange capacity is one of the buffering mechanisms in soil ${ }^{20}$, sometimes taken into account in the calculation of soil liming requirements ${ }^{21}$. Concerning the influence of clay content observed, ref. ${ }^{9}$ also observed consistently lower $\mathrm{N}_{2} \mathrm{O}$ emission for fine-textured soils. During the field experiments, we observed the abatement of $\mathrm{N}_{2} \mathrm{O}$ emissions due to liming, with a simultaneous increase in soil $\mathrm{pH}$ and the capacity of soil to reduce $\mathrm{N}_{2} \mathrm{O}$, while the ancillary variables generally known to affect soil $\mathrm{N}_{2} \mathrm{O}$ emission (soil moisture, temperature and mineral nitrogen contents) were not affected by liming. The $\mathrm{pH}$ effect was observed to occur rapidly, in accordance with the mechanism of posttranscriptional interference of the expression of nos $Z^{23}$. The abatement values we obtained $(26 \%, 49 \%$ and $66 \%)$ appear reasonable, as a rough current estimation as ref. ${ }^{26}$ also reported $\mathrm{N}_{2} \mathrm{O}$ emission abatement values from $16 \%$ to $64 \%$ due to liming and as a function of soil type, temperature, urine amendment and liming rate. Moreover, ref. ${ }^{27}$ reported values between $60 \%$ and $73 \%$ after the application of dolomite to an acidic soil. It generally appears that abatement due to liming can be considerable at the field scale but varies with temperature, rainfall and nitrogen availability as well as the relative contribution of nitrification 


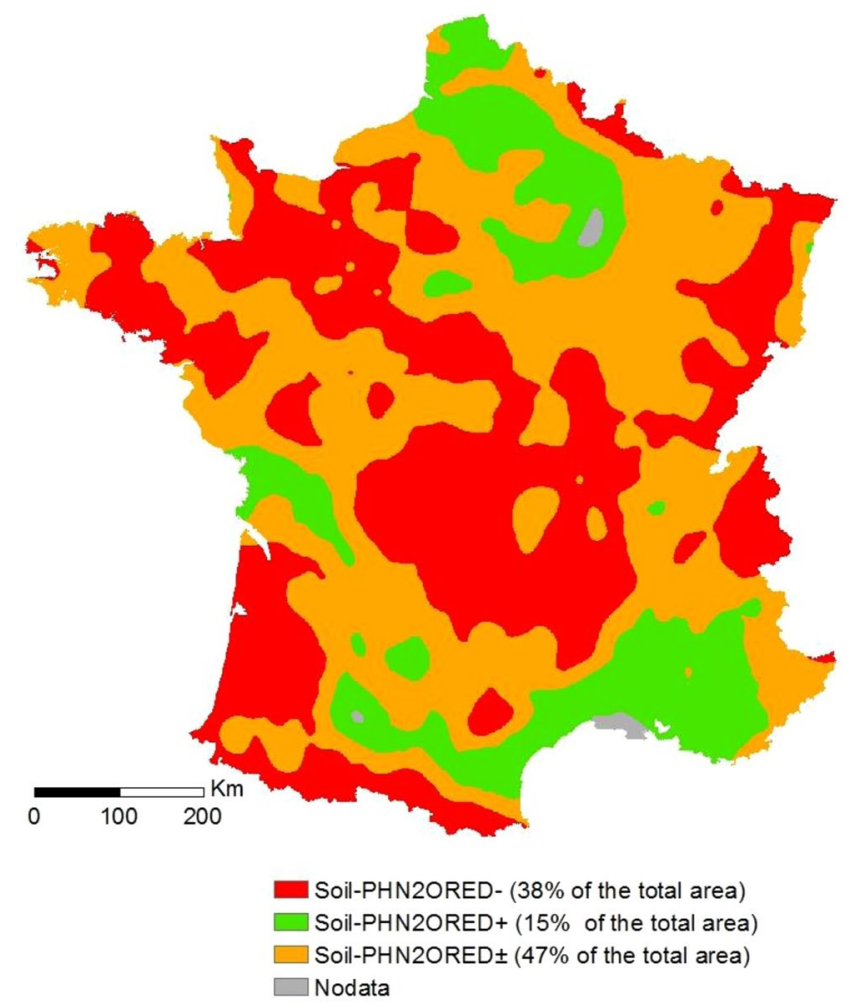

Figure 5. Map of soil $\mathrm{N}_{2} \mathrm{O}$ reduction phenotypes in France obtained from the RMQS database.

and denitrification in $\mathrm{N}_{2} \mathrm{O}$ production. In this study, the application of the NOE algorithm ${ }^{28}$ (Supplementary Information 5) to the database collected (Supplementary Dataset 1) suggested that (i) in E1, where $\mathrm{N}_{2} \mathrm{O}$ emissions were high, these emissions were mainly due to denitrification whereas (ii) in $\mathrm{E} 2$, where $\mathrm{N}_{2} \mathrm{O}$ emissions remained low, nitrification was the main process involved in them. Therefore, both the observed and simulated abatements obtained by managing soil $\mathrm{pH}$ and thus the soil $\mathrm{N}_{2} \mathrm{O}$ reduction path, (as relative and absolute values), were higher in E1 than in E2. While we were not able to definitively define how abatement can vary with fertilisation and rainfall, it seems that the abatement would be higher in situations where denitrification dominates nitrification, as the source of $\mathrm{N}_{2} \mathrm{O}$. While these situations are expected to emit the highest $\mathrm{N}_{2} \mathrm{O}$ emissions, the abatement rate could increase with $\mathrm{N}_{2} \mathrm{O}$ emission rates. Nevertheless, this would require more investigations. The use of isotopic techniques to characterise the $\mathrm{N}_{2} \mathrm{O} / \mathrm{N}_{2}$ ratio as well as the contribution of nitrification/denitrification to $\mathrm{N}_{2} \mathrm{O}$ emissions combined with a modelling approach in experimental situations appears to be a promising methodology for clarifying the combined effect of agronomic and environmental factors on the abatement rate.

Regarding the spatial up-scaling approach, all the relationships we defined, i.e., between soil $\mathrm{N}_{2} \mathrm{O}$ reduction and $\mathrm{pH}$ and between soil $\mathrm{N}_{2} \mathrm{O}$ reduction and $\mathrm{pH}, \mathrm{CEC}$ and clay content (PTF functions), can be applied to all soils in France, regardless of their use (i.e. crops, grassland and forest) or characteristics. This is in agreement with the results obtained by ref. ${ }^{29}$, which can be summarized as "the ratio of denitrification products is $\mathrm{pH}$-specific rather than soil-specific". Consistencies between our results and the literature ${ }^{22-24}$ suggest that the functions proposed are valid not only in France but perhaps also in different parts of the world (e.g., China). Nevertheless, this requires testing, primarily in countries with a soil monitoring network or with a soil properties database, for reasons of experimental facility.

As far as applicability (the relevant soil surface on which the solution can be applied) is concerned, consistent with the laboratory and field results obtained in this study, we defined this surface as an initial but necessary approach based solely on soil $\mathrm{pH}$ and/or the capacity to reduce $\mathrm{N}_{2} \mathrm{O}$. We then calculated a high applicability value for France, but this value should be considered as a potential value. To go further with the liming solution for mitigating GHG emissions, several agronomic, environmental and socio-economic criteria would have to be introduced in the definition of applicability. Concerning agronomic criteria, further investigations are required to estimate surface areas vulnerable to the development of crop diseases attributable to increased soil $\mathrm{pH}$ and to deficiencies in trace elements ${ }^{25}$. Concerning environmental criteria, it will be essential to consider the impact of liming on other components of the greenhouse effect. An initial approach based on the current IPCC guideline ${ }^{30}$ suggests that enhanced $\mathrm{CO}_{2}$ emissions could roughly offset avoided $\mathrm{N}_{2} \mathrm{O}$ emissions in the case where all the $\mathrm{C}$ in the lime applied is emitted as $\mathrm{CO}_{2}$ in the year of application and that the duration of the effect of liming would be no longer than one year. Although the effect of liming on $\mathrm{CO}_{2}$ emissions is still subject to debate ${ }^{31-33}$ and the duration of the effect of liming is generally observed over several years ${ }^{34,35}$, we developed a preliminary calculation of the GHG balance obtained by liming. These calculations currently remain relatively global and do not consider the diversity of liming materials ${ }^{20}$ or specific soil requirements ${ }^{21}$. They are also quite uncertain due to perfectible knowledge on the fate of liming products in soils (ref. ${ }^{31}$ suggested that $\mathrm{CO}_{2}$ emissions after liming 
may be less than half the maximum value due to the transport of dissolved inorganic $\mathrm{C}$ through rivers and lakes to the ocean), and on their effects on carbon (e.g., carbon storage ${ }^{36}$ ) and nitrogen cycles (currently the avoidance of $\mathrm{N}_{2} \mathrm{O}$ emissions). We then developed a methodology to calculate the GHG balance of liming (Supplementary Information 6). This methodology included (i) defining liming conditions ( $\mathrm{pH}$ increase objectives, the need for a neutralizing value, type of product, frequency of application), (ii) defining $\mathrm{CO}_{2}$ emissions per application (during product preparation, during its transportation and application, during its presence in soils), (iii) defining greenhouse gas (GHG) benefits per application (soil organic storage ${ }^{36,37}$, avoided $\mathrm{N}_{2} \mathrm{O}$ emissions) and (iv) calculating the balance between $\mathrm{CO}_{2}$ emissions and GHG benefits. We then applied this methodology to several cases studies: (i) $\mathrm{CaO}$ and $\mathrm{CaCO}_{3}$ as liming materials, (ii) the requirement of 1000 and of 2500 neutralizing values (NV), and (iii) 2 hypotheses on the fate of liming products in soils (hypothesis that suggests that all $\mathrm{C}$ in liming products is transformed into $\mathrm{CO}_{2}$ in soils ${ }^{30}$ and hypothesis which considers that only half of the $\mathrm{C}$ in liming products is transformed into $\mathrm{CO}_{2}{ }^{31}$. We also introduced values from the scientific and technical literature (the $\mathrm{CO}_{2}$ emissions during product preparation kindly provided by the European Lime association, soil C storage ${ }^{36}$, the duration of the effect of liming products on soil $\mathrm{pH}^{34,35}$ and thus on soil $\mathrm{N}_{2} \mathrm{O}$ emissions). Whatever the product type, and for both hypothesis concerning the fate of carbonate in soils ${ }^{30,31}$, the GHG balance appeared positive for an application of $1000 \mathrm{NV} \mathrm{ha}^{-1}$. For an application as high as $2500 \mathrm{NV} \mathrm{ha}^{-1}$, the GHG balance appeared negative under the IPCC hypothesis for the two materials, but positive under the other hypothesis ${ }^{31}$ for carbonated products. Moreover, it should be noted that (i) national inventories currently explicitly consider $\mathrm{CO}_{2}$ emissions resulting from the application of lime, (ii) by-products exist with liming properties that could be utilised in certain situations ${ }^{20}$, (iii) very recently, ref. ${ }^{38}$ suggested that the addition of crushed, fast reacting silicate rocks to croplands could also provide a combined strategy for $\mathrm{CO}_{2}$ removal and that (iv) $\mathrm{N}_{2} \mathrm{O}$ is also involved in stratospheric ozone depletion ${ }^{1}$.

Moreover, ref. ${ }^{39}$ reported that mineral $\mathrm{N}$ fertilization induced acidification and disturbed $\mathrm{N}_{2} \mathrm{O}$ reduction, therefore resulting in increased $\mathrm{N}_{2} \mathrm{O}$ emissions. In addition to mineral fertilization, no-tillage can decrease soil $\mathrm{pH}^{40}$ and may therefore promote $\mathrm{N}_{2} \mathrm{O}$ emissions by slowing soil $\mathrm{N}_{2} \mathrm{O}$ reduction. The indirect effects of these practices on $\mathrm{N}_{2} \mathrm{O}$ reduction would also have to be considered in the future.

While liming as a solution could represent a significant cost for farmers, we also suggest expanding biotechnical research to encompass economic studies in the framework of ecosystemic climate regulation services, in view to sharing the cost of this possible multi-beneficiary mitigation action.

So far, although further biotechnical research is still required, especially in order not to create new sources of $\mathrm{CO}_{2}$ by decreasing $\mathrm{N}_{2} \mathrm{O}$ emissions, it seems that the agricultural sector, together with its stakeholders ${ }^{41}$, is capable of organising the combined application of solutions such as liming, $\mathrm{N}$ fertilization optimization, and using leguminous crops to decrease its GHG emissions. Finally, this study provided new and useful quantitative data (i) on the relationship between soil $\mathrm{pH}$ and the $\mathrm{N}_{2} \mathrm{O}$ reduction path, and (ii) on the potential of $\mathrm{N}_{2} \mathrm{O}$ emission mitigation at the plot and national scales by liming acidic soils and preventing soil acidification. The precautionary principle requires that the fate of the carbon added to soil when liming, as well as changes in sensitivity to crop disease should be investigated further before the large-scale deployment of this solution. We finally recommend that possible large-scale deployment should be based on local studies focusing on agronomic (local risk of disease and deficiencies), environmental $\left(\mathrm{CO}_{2} / \mathrm{N}_{2} \mathrm{O}\right.$ balance) and economic aspects.

\section{Materials and Methods}

Laboratory determination of the capacity of soil to reduce $\mathrm{N}_{2} \mathrm{O}$. The capacity of soil to reduce $\mathrm{N}_{2} \mathrm{O}$ was determined on selected samples from the French Soil Monitoring Network (RMQS) ${ }^{10}$, of which numerous biogeochemical properties are known (Supplementary Information S1_1). The selection was performed using the conditioned Latin hypercube sampling (cLHS) method ${ }^{42}$. This method is a stratified random procedure that provides an efficient way of sampling variables from their multivariate distributions. The aim of the sampling plan was to obtain samples distributed over the entire surface of the country, covering the national gradient of $\mathrm{pH}$ and organic carbon, and land-use. Specific soil samples were collected from the 0-27 $( \pm 4) \mathrm{cm}$ soil layer from September 2012 to December 2015 according to the RMQS methodology ${ }^{43}$. Soil pH was also determined on 90 fresh RMQS samples, in accordance with ISO 10390:2005 ( $\mathrm{pH}$ in $\left.\mathrm{H}_{2} \mathrm{O}\right)$.

The capacity of soil to reduce $\mathrm{N}_{2} \mathrm{O}$ was determined in the laboratory according to ISO/TS 20131-2 derived from ref. ${ }^{8}$. Four sets of incubation under anaerobic conditions were established using fresh soil samples sieved through a 5-mm mesh. Each set included three replicates equivalent to $50 \mathrm{~g}$ of dry soil placed in $565-\mathrm{ml}$ flasks. Two series of incubations were carried out with the addition of $\mathrm{NO}_{3}{ }^{-}\left(50 \mathrm{ml} \mathrm{KNO}_{3}\right.$ solution with $\left.100 \mathrm{mgl}^{-1}\right)$, (1) in the presence of acetylene (2.5\% of the gas atmosphere), and (2) without the addition of acetylene. These two series were used to determine the part of $\mathrm{N}_{2} \mathrm{O}$ emitted over time during the denitrification process. Two other series of incubations were carried out with the addition of water $(50 \mathrm{ml})$ and $\mathrm{N}_{2} \mathrm{O}(5 \mathrm{ml})$ (1) in the presence of acetylene and (2) without acetylene. Due to reservations regarding the acetylene methodology ${ }^{44}$, the aim of these two series of incubations was to validate the total inhibition of $\mathrm{N}_{2} \mathrm{O}$ reductase by acetylene in our experimental conditions. Anaerobic conditions in the flasks were established before gas addition by three successive cycles of emptying and refilling with $\mathrm{N}_{2}$. The kinetics at $20^{\circ} \mathrm{C}$ were determined over a period of one week with the flasks under constant agitation on a rotating shaker. The flasks were periodically sampled in pre-emptied flasks before analysis on a $\mu \mathrm{GC}$ (SRA Instruments T3000) equipped with a TCD detector. The results of this test could be represented in a graph of the quantity of $\mathrm{N}_{2} \mathrm{O}$ produced in flasks over time for the two treatments with nitrate addition and synthetized through two indicators, $\mathrm{r}_{\max }$ and index. $\mathrm{r}_{\max }$ is the maximum ratio of the accumulated $\mathrm{N}_{2} \mathrm{O}$ during incubation, with $\mathrm{r}$ being the ratio between $\mathrm{N}_{2} \mathrm{O}$ produced during incubation without acetylene to $\mathrm{N}_{2} \mathrm{O}$ produced during incubation with acetylene, at each time point. The index combines information on the level of $r_{\max }$ and on the time of accumulation of $\mathrm{N}_{2} \mathrm{O}$ during incubation. The higher the $\mathrm{r}_{\max }$ and index are, the lower the capacity of soil to reduce $\mathrm{N}_{2} \mathrm{O}$. Supplementary Information 2 illustrates this method for three soils studied in this study. ISO/TS 20131-2, annex A, indicates that soils with an index higher than 50 are especially suspected to emit very 
high levels of $\mathrm{N}_{2} \mathrm{O}$ due to low $\mathrm{N}_{2} \mathrm{O}$ reduction activity. An index higher than 50 generally corresponds either to an absence of $\mathrm{N}_{2} \mathrm{O}$ reduction $(\mathrm{r} \geq 1)$ over a period of at least 48 hours or to a very poor reduction of $\mathrm{N}_{2} \mathrm{O}(\mathrm{r} \sim 0.8)$ over a period of at least $72 \mathrm{~h}$. We generally consider that soils are poorly able to reduce $\mathrm{N}_{2} \mathrm{O}$ when the index is higher than 50 or when $r_{\max }$ is higher than 0.8 . Soils are very effective at reducing $\mathrm{N}_{2} \mathrm{O}$ when the $\mathrm{r}_{\max }$ and index are lower than 0.4 and 30 , respectively.

The statistical methods applied to the obtained database mainly include linear regression and partial least square regression (PLS) ${ }^{12}$, generalized boosted models $(\mathrm{GBMs})^{13}$ and classification and regression trees $(\mathrm{CART})^{14}$ coupled to factorial discriminant analysis (FDA $)^{15}$. CART and FDA were applied to $98 \%$ of the studied RMQS subset, using index values related to soil $\mathrm{pH}$ to define $\mathrm{pH}$-index classes.

Field experiment for soil $\mathrm{N}_{2} \mathrm{O}$ emission measurement. In addition to the laboratory tests, two experimental block trials (E1 and E2) were performed at the field scale. They involved cultivated fields managed by French technical Institutes, with soils that were initially acidic and hardly able to reduce $\mathrm{N}_{2} \mathrm{O}$. E1 was dedicated to the effect of liming and E2 to the effect of liming and the addition of organic matter.

The E1 experiment was conducted (initial $\mathrm{pH}<6.0$ ) on the Arvalis-Institut du Végétal domain of La Jaillière (France, $57.451^{\circ} \mathrm{N}, 0.966^{\circ} \mathrm{W}$ ) in $2013-2014$ and $2014-2015$. The soil at this experimental site is composed of gleyic cambisols lying on an alterite consisting of sandstony schist, widely observed in the West of France. The texture class of the arable soil is 'loamy silty sand' with a carbon content of $1.3 \%$. The climate at this site is of oceanic type with an average temperature of $12.5^{\circ} \mathrm{C}$ and a mean annual precipitation of $730 \mathrm{~mm}$. The site is generally cultivated with a succession of Maize, Maize, Wheat. During this experiment, E1 was successively cultivated with fertilized maize and wheat. $\mathrm{pH}$ management consisted of the addition of $1 \mathrm{t} \mathrm{CaO} \mathrm{ha}{ }^{-1}$ in September 2013 and in September 2014. During the first year of the experiment, nitrogen fertiliser was spread once at the 3-leaf stage on $14 / 05 / 2014$, with $60 \mathrm{~kg}$ of $\mathrm{N} \mathrm{ha}^{-1}$ (33.5\% ammonium nitrate). During the second year of the experiment, three inputs of nitrogen were spread in spring using ammonium nitrate at $33.5 \%: 70 \mathrm{~kg}$ of N ha ${ }^{-1}$ on 09/03/2015, then $50 \mathrm{~kg}$ of $\mathrm{N} \mathrm{ha}^{-1}$ on $30 / 03 / 2015$, and lastly $60 \mathrm{~kg}$ of $\mathrm{N} \mathrm{ha}^{-1}$ on $10 / 05 / 2015$.

The $\mathrm{E} 2$ experiment was conducted (initial $\mathrm{pH}<5.6$ ), on a field managed by Terres Inovia at Presly la Noue (France, $47.388^{\circ} \mathrm{N}, 2.357^{\circ} \mathrm{E}$ ) in $2013-2014$. The soil was podzolic, the texture class of the arable field was 'sandy loamy' and the carbon content was $1.9 \%$. The climate at the site is of oceanic type with an average temperature of $10.7^{\circ} \mathrm{C}$ and a mean annual precipitation of $710 \mathrm{~mm}$. Prior to the experiment the soil of E2 was kept bare. During $\mathrm{E} 2$, the soil was cultivated with fertilized mustard. $\mathrm{pH}$ management consisted of the addition of $1.5 \mathrm{t} \mathrm{CaO} \mathrm{ha}{ }^{-1}$ to $\mathrm{E} 2$. $\mathrm{CaO}$ was added at the time of implantation, with burial immediately after input at a depth of $10 \mathrm{~cm}$. Soil organic matter management consisted of the addition of $27 \mathrm{~m}^{3} \mathrm{ha}^{-1} \mathrm{y}^{-1}$ of pork liquid manure. The lime and manure were spread one week before seeding the crop (winter rapeseed) so as not to risk damaging the seed and jeopardising emergence. The pig manure was spread at a rate of $25 \mathrm{~m}^{3} \mathrm{ha}^{-1}$. Mineral fertilisers were spread during two events: the first input was $50 \mathrm{~kg} \mathrm{~N} \mathrm{ha}^{-1}$ on $2 / 05 / 2014$ and the second was $50 \mathrm{~kg} \mathrm{~N} \mathrm{ha}^{-1}$ on $9 / 05 / 2014$. Only the "pig manure" plots did not receive the second input. Additional agricultural technical processes are described in Supplementary Information 7.

Field sites were organized in random blocks with three blocks per treatment; each block consisted of three chambers. In situ $\mathrm{N}_{2} \mathrm{O}$ emission measurements were performed using the manual chamber method coupled with gas chromatography (electron capture detector) analysis ${ }^{45,46}$. All the $\mathrm{N}_{2} \mathrm{O}$ measurements also included measurements of the ancillary variables (soil moisture, mineral nitrogen and temperature). Soil moisture and mineral nitrogen determinations involved 1 replicate per block (i.e. 3 replicates per treatment), each obtained from a composite of 10 soil samples collected with an auger. The $\mathrm{pH}$ and capacity to reduce $\mathrm{N}_{2} \mathrm{O}$ were determined periodically on these soil samples. Soil temperature was directly measured in the field.

The Wilcoxon signed rank test was used site per site to test the null hypothesis that the treatments (liming and organic matter addition in comparison with control) did not affect soil $\mathrm{N}_{2} \mathrm{O}$ emission over each annual period of measurements $(\mathrm{p}<0.05)$ and did not affect soil ancillary variables $(\mathrm{p}<0.05)$. In the case where this hypothesis was rejected, we used student's t-test to determine the dates with significant differences $(\mathrm{p}<0.05)$. The combined effect of ancillary variables was analysed using the NOE algorithm ${ }^{28}$. Except, the specific $r_{\max }$ values to each situation, all the other biological parameters required by NOE were measured on E1. The Wilcoxon signed rank test was used site per site to test the null hypothesis that the dynamics of measures and simulations were not different $(\mathrm{p}<0.05)$. We also used the RMSE criteria to evaluate the quality of the simulations.

Upscaling to the national scale. We used different approaches ("CART-FDA", "cumulative frequency", "map_rmqs") for calculating the potential applicability of soil liming for reducing $\mathrm{N}_{2} \mathrm{O}$. The use of different relevant approaches allows for the proposal of an interval of estimated values.

As far as the "CART-FDA" approach is concerned, the previously defined classes of index-pH were applied to the soil $\mathrm{pH}$ of the total RMQS to assess the index frequency of cultivated soils and of fertilized grassland soils at the national scale. Thresholding consisted of evaluating the surface of soils in the different classes of $\mathrm{pH}$-index.

During the "cumulative frequency approach", we determined the cumulative frequencies of soil $\mathrm{pH}$, soil $\mathrm{r}_{\max }$ and soil index. We assessed the soil $r_{\max }$ and soil index by applying Eqs. 1 and 2 to the entire RMQS database. For $\mathrm{pH}$ as phenotype indicator, thresholding was applied to quantify the surface of soils having a $\mathrm{pH}$ lower than 6.8 ([soil $]_{\mathrm{PHN}_{2} \mathrm{ORED}_{2} /- \text { and } \mathrm{PHN}_{2} \mathrm{ORED}_{-}}$), soils having a pH lower than 6.4 ([soil $\left.]_{\mathrm{PHN}_{2} \mathrm{ORED}-}\right)$. For $\mathrm{r}_{\max }$, in accordance with both ISO/TS20141-2 and the GBM function, thresholding was applied to quantify the surface of soils having a predicted $\mathrm{r}_{\max }$ higher than 0.4 ([soil $]_{\mathrm{PHN}_{2} \mathrm{ORED}+/- \text { and } \mathrm{PHN}_{2} \mathrm{O}_{\mathrm{RED}}-}$ ) and especially the surface of soils having a $\mathrm{r}_{\max }$ higher than 0.8 ([soil $\left.]_{\mathrm{PHN}_{2} \mathrm{ORED}-}\right)$. Concerning the index, thresholding was applied to quantify the surface of soils having a predicted index value higher than 30 ([soil $]_{\mathrm{PHN}_{2} \mathrm{ORED} /- \text { and } \mathrm{PHN}_{2} \mathrm{ORED}-}$ ) and especially higher than 50 ([soil $\left.]_{\mathrm{PHN}_{2} \mathrm{ORED}-}\right)$. Finally, we estimated the surface of soils for each phenotype as the median surface obtained using each indicator. 
As far as the "map_rmqs approach" was concerned, we first mapped soil pH, CEC and the clay content by kriging. We then inferred the $r_{\max }$ map over the whole of France's continental area using Eq. 1 (Fig. 5A). A thresholding with $\mathrm{r}_{\max } \geq 0.8$ corresponding to [soil $]_{\mathrm{PHN}_{2} \mathrm{ORED}_{-}-}, \mathrm{r}_{\max }<0.4$ corresponding to [soil $]_{\mathrm{PHN}_{2} \mathrm{ORED}+\text {, and }}$ $0.4 \leq \mathrm{r}_{\max }<0.8$ corresponding to [soil $]_{\mathrm{PHN}_{2} \mathrm{ORED}+/-}$ was then applied to define the potential applicability of liming to reduce $\mathrm{N}_{2} \mathrm{O}$ emissions at the national scale.

\section{Data availability}

Data are available on request from catherine.henault@inra.fr.

Received: 31 January 2019; Accepted: 15 December 2019;

Published online: 27 December 2019

\section{References}

1. UNEP, Drawing down N2O to protect climate and ozone layer. A UNEP synthesis report. United Nations Environment Programme (UNEP). Nairobi, Kenya (2013).

2. Myhre, G. et al. Anthropogenic and Natural Radiative Forcing. In: Climate Change 2013: The Physical Science Basis. Contribution of Working Group I to the Fifth Assessment Report of the Intergovernmental Panel on Climate Change [Stocker, T. F. et al. (eds)]. (Cambridge University Press, Cambridge, United Kingdom and New York, NY, USA, 2013).

3. Paustian, K. et al. Climate-smart soils. Nature. 532, 49-57 (2016).

4. Butterbach-Bahl, K., Baggs, E., Dannenmann, M., Kiese, R. \& Zechmeister-Boltenstern, S. Nitrous oxide emissions from soils: how well do we understand the processes and their controls. Phil. Trans. R. Soc. B. 368, 20130122 (2013).

5. Pellerin, S. et al. Identifying cost-competitive greenhouse gas mitigation potential of French agriculture. Environ. Sci. Policy. 77, 130-139 (2017)

6. Henry, S., Bru, D., Stres, B., Hallet, S. \& Philippot, L. Quantitative detection of the nosZ gene, encoding nitrous oxide reductase, and comparison of the abundances of 16S rRNA, narG, nirK, and nosZ genes in soils. Appl. Environ. Microb. 72, 5181-5189 (2006).

7. Yoshinari, T. \& Knowles, R. Acetylene inhibition of nitrous oxide reduction by denitrifying bacteria. Biochem. Bioph. Res. Co. 69, 705-710 (1976).

8. Hénault, C. et al. Laboratory kinetics of soil denitrification are useful to discriminate soils with potentially high levels of $\mathrm{N}_{2} \mathrm{O}$ emission on the field scale. Agronomie. 21, 713-723 (2001).

9. Stehfest, E. \& Bouwmann, L. $\mathrm{N}_{2} \mathrm{O}$ and $\mathrm{NO}$ emission from agricultural fields and soils under natural vegetation: summarizing available measurement data and modeling of global annual emissions. Nutr. Cycl. Agroecosys. 74, 207-228 (2006).

10. Arrouays, D. et al. Le Réseau de Mesures de la Qualité des Sols de France (RMQS). Etude et Gestion des Sols 10, 241-250 (2003)

11. Phillips, D. J. Soils as extended composite phenotypes. Geoderma 149, 143-151 (2009).

12. Wold, S., Ruhe, A., Wold, H. \& Dunn, W. J. III The collinearity problem in linear regression. The partial least squares (PLS) approach to generalized inverses. SIAM J Sci Stat Comput. 3, 735-743 (1984).

13. Friedman, J. H. Stochastic Gradient Boosting. Comput Stat Data An. 38(4), 367-378 (2002).

14. Breiman, L., Fiedman, J. H., Olshen, R. A. \& Stone, C. J. Classification and Regression trees. (Wadsworth, 1984).

15. Tomassone, R., Danzart, M., Daudin, J. J. \& Masson, J. P. Discrimination et classement. (Masson, Paris, 1988).

16. Ciesielski, H., Sterckeman, T., Santerne, M. \& Willery, J. P. A comparison between three methods for the determination of cation exchange capacity and exchangeable cations in soils. Agronomie 17, 9-16 (1997).

17. Ciesielski, H., Sterckeman, T., Santerne, M. \& Willery, J. P. Determination of cation exchange capacity and exchangeable cations in soils by means of cobalt hexamine trichloride. Effects of experimental conditions. Agronomie 17, 1-7 (1997).

18. Jaremko, D. \& Kalembasa, D. A comparison of methods for the determination of cation exchange capacity of soils. Ecol. Chem. Eng. S. 21, 487-498 (2014)

19. Grundmann, G. L., Rolston, D. E. \& Kachanoski, R. G. Field soil properties influencing the variability of denitrification gas fluxes. Soil Sci. Soc. Am. J. 52, 1351-1355 (1988).

20. Goulding, K. W. T. Soil acidification and the importance of liming agricultural soils with particular reference to the United Kingdom. Soil Use Manage. 32, 390-399 (2016).

21. Merry, R. H. Acidity and alkalinity of soils. Encyclopedia of Life Support Systems (EOLSS). ISBN-978-1-84826-206-5. pp 115-131 (Eolss Publishers Co. Ltd, Oxford, UK, 2009).

22. Wang, Y. et al. Soil $\mathrm{pH}$ as the chief modifier for regional nitrous oxide emissions: new evidence and implications for global estimates and mitigation. Glob Change Biol. 24, e617-e626 (2018).

23. Liu, B., Frostegård, A. \& Bakken, L. Impaired reduction of $\mathrm{N}_{2} \mathrm{O}$ to $\mathrm{N}_{2}$ in acid soils is due to a posttranscriptional interference with the expression of nosZ. mBio. 5, e0183-14 (2014).

24. Sun, P., Zhuge, Y., Zhang, J. \& Cai, Z. Soil pH was the main controlling factor of the denitrification rates and $\mathrm{N}_{2} / \mathrm{N}_{2} \mathrm{O}$ emission ratios in forest and grassland soils along the Northeast China Transect (NECT). Soil Sci. Plant Nutr. 58, 517-525 (2012).

25. Holland, J. E. et al. Liming impacts on soils, crops and biodiversity in the UK: A review. Sci. Total Environ. 610-611, 316-332 (2018).

26. McMillan, A. S. et al. Can pH amendments in grazed pastures help reduce $\mathrm{N}_{2} \mathrm{O}$ emissions from denitrification? - The effects of liming and urine addition on the completion of denitrification in fluvial and volcanic soils. Soil Biol Biochem. 93, 90-104 (2016).

27. Shaaban, M. et al. Dolomite application to acidic soils: a promising option for mitigating $\mathrm{N}_{2} \mathrm{O}$ emissions. Environ Sci Pollut Res. 22, 19961-19970 (2015).

28. Hénault, C. et al. Predicting in situ soil $\mathrm{N}_{2} \mathrm{O}$ emission using NOE algorithm and soil database. Glob. Change Biol. 11, 115-127 (2005).

29. Čuhel, J. \& Šimek, M. Effect of pH on the denitrifying enzyme activity in pasture soils in relation to the intrinsic differences in denitrifier communities. Folia Microbiol. 56, 230-235 (2011)

30. De Klein, C. et al. $\mathrm{N} 2 \mathrm{O}$ emissions from managed soils, and $\mathrm{CO}_{2}$ emissions from lime and urea application. 2006 IPCC Guidelines for National Greenhouse Gas Inventories. Volume 4: Agriculture, Forestry and Other Land Use. 54 p. (2006).

31. West, T. O. \& McBride, A. C. The contribution of agricultural lime to carbon dioxide emissions in the United States: dissolution, transport, and net emissions. Agr Ecosyst Environ. 108, 145-154 (2005).

32. Hamilton, S., Kurzman, A., Arango, C., Jin, L. \& Robertson, P. Evidence for carbon sequestration by agricultural liming. Global Biogeochem Cy. 21, GB2021 (2007).

33. Shaaban, M. et al. Influence of ameliorating soil acidity with dolomite on the priming of soil C content and $\mathrm{CO}_{2}$ emission. Environ Sci Pollut Res. 24, 9241-9250 (2017).

34. Pagani, A. \& Mallarino, A. Soil pH and crop grain yield as affected by the source and rate of lime. Soil Sci. Soc. Am. J. 76, 1877-1886 (2012).

35. Flower, K. C. \& Crabtree, W. L. Soil pH change after surface application of lime related to the levels of soil disturbance caused by no-tillage seeding machinery. Field Crops Res. 121, 75-87 (2011).

36. Paradelo, R., Virto, I. \& Chenu, C. Net effect of liming on soil organic carbon stocks: A review. Agric. Ecosys. Env. 202, 98-107 (2015). 
37. Fornara, D. A. et al. Increases in soil organic carbon sequestration can reduce the global warming potential of long-term liming to permanent grassland. Glob Change Biol. 17, 1925-1934 (2011).

38. Beerling, D. J. et al. Farming with crops and rocks to address global climate, food and soil security. Nat Plants, https://doi. org/10.1038/s41477-018-0108-y (2018).

39. Raut, N., Dörsch, P., Sitaula, B. K. \& Bakken, L. R. Soil acidification by intensified crop production in South Asia results in higher $\mathrm{N}_{2} \mathrm{O} /\left(\mathrm{N}_{2}+\mathrm{N}_{2} \mathrm{O}\right)$ product ratios of denitrification. Soil. Biol. Biochem. 55, 104-112 (2012).

40. Rahman, M. H., Okubo, A., Sugiyama, S. \& Mayland, H. F. Physical, chemical and microbiological properties of an Andisol as related to land use and tillage practice. Soil Tillage Res. 101, 10-19 (2008).

41. Decock, J. L., Necpalova, M., Pereira, E. I. P., Tendall, D. M. \& Six, J. Mitigating $\mathrm{N}_{2} \mathrm{O}$ emissions from soil: from patching leaks to transformation action. Soil. 1, 687-695 (2015).

42. Mismany, B. \& McBratney, A. B. A conditioned Latin hypercube method for sampling in the presence of ancillary information. Comput Geosci-UK. 32, 1378-1388 (2006).

43. Jolivet, C., Boulonne, L. \& Ratié, C. Manuel du Réseau de Mesure de la Qualité des Sols. Edition 2006, Unité InfoSol, INRA Orléans, France, 190 p. (2006)

44. Groffman, P. M. et al. Methods for measuring denitrification, Diverse approaches to a difficult problem. Ecol. Appl. 16, 2091-2122 (2006).

45. Gu, J. et al. A regional experiment suggests that soil texture is a major control of $\mathrm{N}_{2} \mathrm{O}$ emissions from tile-drained winter wheat fields during the fertilization period. Soil Biol Biochem. 60, 134-141 (2013).

46. Jeuffroy, M. J. et al. Nitrous oxide emissions from crop rotations including wheat, oilseed rape and dry peas. Biogeosciences. 10, 1787-1797 (2013).

\section{Acknowledgements}

This study was supported by the REACCTIF program of the French Agency for Environment and Energy Management (ADEME) through the projects SOLGES (contract 1260C0040) and CHAUGES (contract 1803C0003). The authors thank the GISSOL for providing access to the RMQS data and methodologies. The authors thank the technical staff of INRA (UR SOLS, INFOSOL), of ARVALIS (La Jaillière) and of Terres Inovia and UCATA (Bourges) for their contributions. They also thank all the students that have contributed to the realisation of this study.

\section{Author contributions}

C.H. led the project and the development of the manuscript. H.B. and N.S. led the statistical and spatial analyses. A.A. performed the laboratory experiments. C.R. coordinated RMQS sampling. J.P.C. coordinated the La Jaillière experiments. C.L.G. coordinated the Presly La Noue experiments and co-led the project along with T.E.

\section{Competing interests}

The authors declare no competing interests.

\section{Additional information}

Supplementary information is available for this paper at https://doi.org/10.1038/s41598-019-56694-3.

Correspondence and requests for materials should be addressed to C.H.

Reprints and permissions information is available at www.nature.com/reprints.

Publisher's note Springer Nature remains neutral with regard to jurisdictional claims in published maps and institutional affiliations.

(c) (i) Open Access This article is licensed under a Creative Commons Attribution 4.0 International

License, which permits use, sharing, adaptation, distribution and reproduction in any medium or format, as long as you give appropriate credit to the original author(s) and the source, provide a link to the Creative Commons license, and indicate if changes were made. The images or other third party material in this article are included in the article's Creative Commons license, unless indicated otherwise in a credit line to the material. If material is not included in the article's Creative Commons license and your intended use is not permitted by statutory regulation or exceeds the permitted use, you will need to obtain permission directly from the copyright holder. To view a copy of this license, visit http://creativecommons.org/licenses/by/4.0/.

(c) The Author(s) 2019 